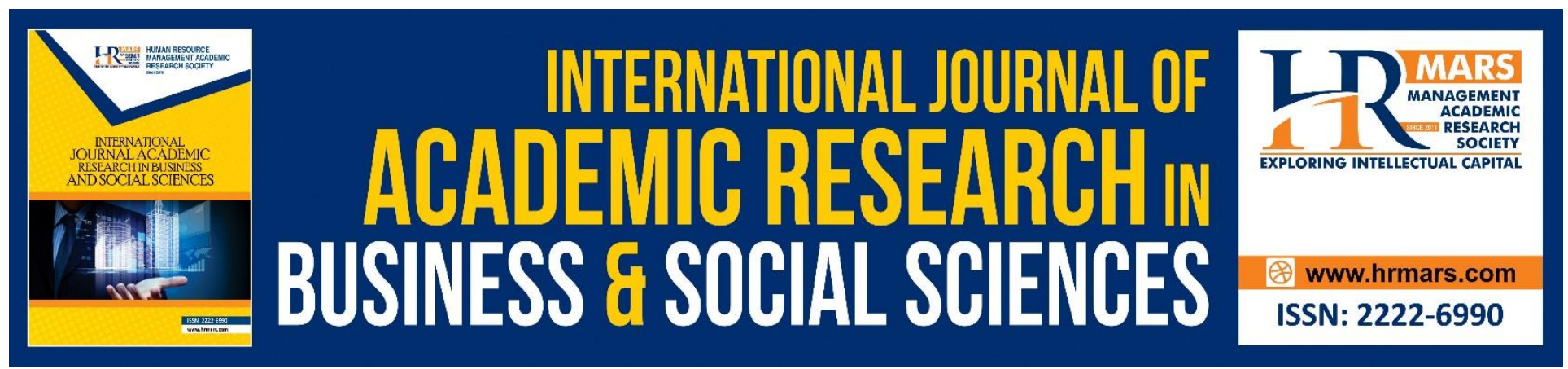

\title{
Knowledge Sharing Tools and their Impact on Enhancing Organizational Performance
}

\section{Abo Bakr Salem bin Mahfodh, Abdallah Mishael Obeidat}

To Link this Article: http://dx.doi.org/10.6007/IJARBSS/v10-i9/7708

DOI:10.6007/IJARBSS/v10-i9/7708

Received: 19 June 2020, Revised: 21 July 2020, Accepted: 17 August 2020

Published Online: 15 September 2020

In-Text Citation: (Mahfodh, \& Obeidat, 2020)

To Cite this Article: Mahfodh, A. B. S. B., \& Obeidat, A. M. (2020). Knowledge Sharing Tools and their Impact on Enhancing Organizational Performance. International Journal of Academic Research in Business and Social Sciences. 10(9), 91-112.

Copyright: (C) 2020 The Author(s)

Published by Human Resource Management Academic Research Society (www.hrmars.com)

This article is published under the Creative Commons Attribution (CC BY 4.0) license. Anyone may reproduce, distribute, translate and create derivative works of this article (for both commercial and non-commercial purposes), subject to full attribution to the original publication and authors. The full terms of this license may be seen at: http://creativecommons.org/licences/by/4.0/legalcode

Vol. 10, No. 9, 2020, Pg. 91 - 112

http://hrmars.com/index.php/pages/detail/IJARBSS

JOURNAL HOMEPAGE

Full Terms \& Conditions of access and use can be found at http://hrmars.com/index.php/pages/detail/publication-ethics 


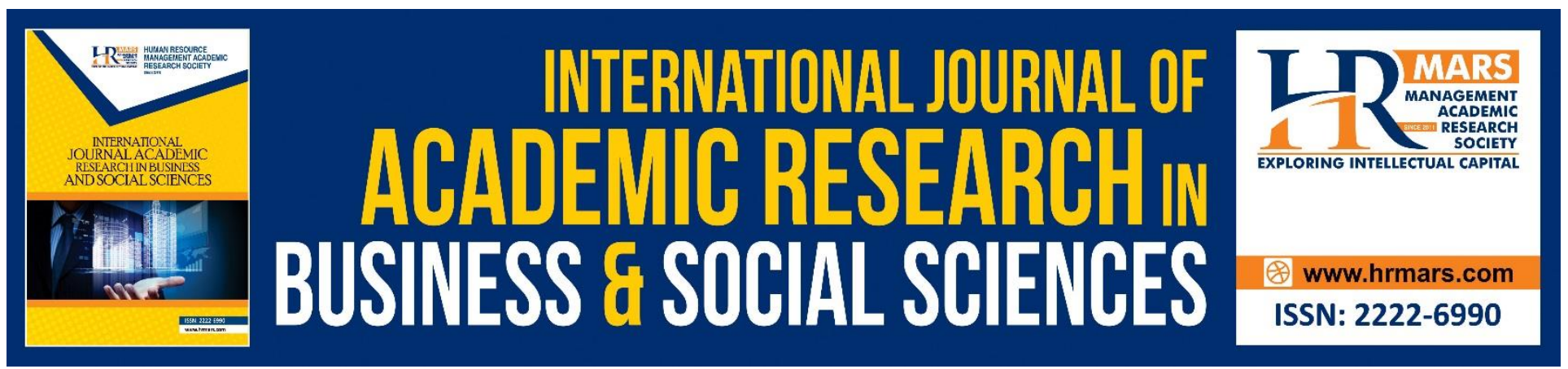

\title{
Knowledge Sharing Tools and their Impact on Enhancing Organizational Performance
}

\author{
Abo Bakr Salem bin Mahfodh \\ Business Administration Department -Business Collage- Jadara University- Jordan. \\ Email: Abc511288@gmail.com \\ Dr. Abdallah Mishael Obeidat \\ Associate Professor, Business Administration Department, Business Collage, Jadara University- \\ Jordan. \\ Email: aabullahh2000@hotmail.com
}

\begin{abstract}
This study aimed to identify the tools for knowledge sharing and its effect on enhancing organizational performance. The researcher applied this study at Jadara University. To achieve the goals of the study and obtain the necessary data for the study, the researcher developed a questionnaire consisting of (40) paragraphs, and the study community reached (420) employees and a simple random sample was chosen from the study community amounting to (201) employees ( Male ( Female) of the Jadara University employees. The study found that there was a statistically significant effect at the significance level $(0.05 \geq \alpha)$ to share knowledge of its dimensions (Organizational Culture, Training, Knowledge Bases, Best Practices) in enhancing organizational performance at Jadara University. In addition to have a statistically significant effect of the dimensions of knowledge sharing in all dimensions of organizational performance. The study recommended creating a climate of trust between workers, creating an organizational culture that encourages knowledge sharing within the team, and spreading best practices to all university employees.
\end{abstract}

Keywords: Knowledge Sharing Tools, Organizational Performance, Efficiency, Creativity, Effectiveness, Jadara University, Jordan

\section{Introduction}

Business organizations face many variables such as globalization, competition, and the digital revolution, which impose on them many challenges that drive them to adopt important strategies for more innovation, creativity and excellence in the performance necessary to survive and continue (Aljawarneh et al, 2020) and the most important of these strategies are those that are based on knowledge management systems, which work To discover the knowledge related to the internal and external environment of the organization, its creation and storage, and then to share this knowledge 
INTERNATIONAL JOURNAL OF ACADEMIC RESEARCH IN BUSINESS AND SOCIAL SCIENCES Vol. 10, No. 9, 2020, E-ISSN: 2222-6990 @ 2020 HRMARS

to maximize its use, leading to its use in the faces that achieve the goals and objectives of these organizations (Rebentisch, 2013; Al Thani \& Obeidat, 2020).

Knowledge sharing is of great benefit to organizations, and despite this, individuals fear that they lose their importance and standing as a result of knowledge sharing that is a source of strength for them, which requires an atmosphere of confidence that allows this knowledge sharing and organizational performance and requires the subject of the process of knowledge sharing from workers in Organizations can interact with each other, either through direct or indirect communication, and by contrast, the hoarding of knowledge is deliberately withholding this knowledge, which would prevent others from benefiting from it (Yaghi, 2011; Obeidat \& Otibi, 2015). The process of knowledge sharing takes multiple forms, and it can be achieved without relying on the presence of technology in some situations, such as direct communication that occurs between individuals in conferences, meetings, training workshops, dialogue sessions, exchanging views, and the method of self-evaluation questionnaires, as these methods are enabled by communication is the acquisition of the tacit knowledge that exists in the minds of individuals, and facilitates the sharing and benefit from it, and this enhances the importance of the role of the human factor in the success of knowledge management and sharing in addition to technology (Obeidat, 2019), information and technology do not represent a little value if you do not find someone to manage them efficiently. Technology plays the catalyst that enables and facilitates the process of knowledge sharing through the Internet. It is a means that improves the mechanism of information exchange and the dissemination and sharing of knowledge, supports cooperation and interconnection between parts of the organization, increases the effectiveness of coordination and access to information better and faster, and facilitates the practice of storms E-mentality, exchange of dialogues and electronic discussions inside and outside the organization (Hassan, 2008)

Organizations seek to be more attention to the issue of performance, and this calls for organizations to focus on the human factor in order to achieve the goals through effective use of resources and exploitation of available opportunities and available potential capabilities. Responding to the needs and expectations of workers (Al-Balawi, 2008). The issue of concern for organizational performance and ways to improve it and achieve effectiveness and efficiency is still a constant concern of business organizations since the nineteenth century and the achievement of the goals for which it was found, and the focus has come on institutions in a way that confirms their reaching goals by raising performance level to ensure continuity, growth and development (Al-Balawi, 2008; AlQudah, 2020). Performance is an important subject that has received ample attention in management studies in general; This is due to the importance of the topic at the organizational and individual level and the overlapping of influences that affect performance and its diversity (Jad alRab, 2010) indicated that access to distinguished job performance for workers is mortgaged and simultaneous with the availability of an acceptable level of services and work and from material and moral justice. Organizational performance occupies a high position in any institution, as the final extract of the outcome of activities in it, at the individual and institution level. Because the institution is more stable and longer lasting when the performance of employees is distinctive, therefore the administration and its leadership pay attention to the level of performance, so the interest in workers is high by the administration. Performance within organizations is not only a reflection of the motivations and capabilities of subordinates, but is also a reflection of the motivations and abilities of chiefs and leaders as well (Sharif, 2004). Organizations are also performance as a key indicator and requirement through which organizations succeed or fail to achieve their goals, which requires 
INTERNATIONAL JOURNAL OF ACADEMIC RESEARCH IN BUSINESS AND SOCIAL SCIENCES Vol. 10, No. 9, 2020, E-ISSN: 2222-6990 @ 2020 HRMARS

finding effective efforts for Promote the level of performance of these organizations efficiently and effectively, and the role of performance appears if it is understood that the change and development in the effectiveness of the organizations and their goals and operations in addition to the performance of workers and what is sought by any organization, and this research came to identify the tools for knowledge sharing and its impact in enhancing organizational performance.

Today's organizations are experiencing a clear change in their circumstances, whether political, cultural, social, or economic conditions (Irtaimeh et al, 2016). This requires organizations to respond to changes in a way that affects improving organizational performance in all governmental and private business organizations. To ensure the survival and continuity of these organizations, and the lack of confidence or their low level in the organization is a factor in the weakness of individuals working to share the knowledge they possess and limiting the organization's ability to enhance organizational performance, and knowledge sharing and organizational performance are important requirements to keep pace with developments and changes and in general is a problem Research in identifying tools for knowledge sharing and its effect on enhancing organizational performance in its dimensions (efficiency, creativity, effectiveness), and the problem of the study appears by answering the following question: What is the effect of using knowledge sharing tools in enhancing organizational performance in Jadara University?

\section{Knowledge Sharing}

Knowledge sharing is one of the most important knowledge management activities, as it is not possible to talk about knowledge sharing within an organization without talking about transferring it; Because the process of knowledge transfer is the critical step towards the process of sharing it (Saffar \& Obeidat, 2020). Knowledge is an integrative, cumulative process that occurs over relatively long periods of time; In order to be available for application and use in order to address specific problems and conditions, knowledge is used to interpret available information about a particular case and to make a decision about how to manage and treat this condition (Alyan, 2007) also,. (Ababneh et al., 2013) defines knowledge transfer as: "Delivering the right knowledge to the right person at the right time, in the right form, and at the right cost."

The importance of knowledge sharing highlights that it helps to understand the nature of the business in the organization, which contributes to improving its performance and helps it to adapt (Al-Mahamid, 2011), and believes that the effective participation of workers helps to achieve the goals of the organization positively; Because the individual and the group feel that the process of achieving their goals through the participatory work in the organization motivates them to maintain and develop them; It produces a spiritual work stemming from trust in others and superiors; It becomes a culture of individuals, and knowledge sharing increases organizational loyalty, so that they consider the challenges facing the organization as a threat to them, to their security and stability, which leads to their acceptance of participation with a desire and a high moral spirit, and the knowledge that individuals possess is one of the assets of the organization that must be managed Effectively; To improve the performance of that organization; And to improve the competitive advantage (Refaiy \& Labib, 2009; Obeidat et al, 2018).

(Swift \& Hwang, 2013) that the employee's knowledge increases his value, so if the organization wants to encourage employees to share that knowledge, it must ensure that it maintains its privileges and benefits arising from its ownership of it in that organization, and is the unwillingness of individuals to share knowledge with Others are a major problem facing organizations (Denning, 2006) 
INTERNATIONAL JOURNAL OF ACADEMIC RESEARCH IN BUSINESS AND SOCIAL SCIENCES

Vol. 10, No. 9, 2020, E-ISSN: 2222-6990 @ 2020 HRMARS

On the other hand, knowledge sharing is considered social behavior, and the various materials, technological, psychological, cultural, and personal factors work to enhance or prevent this activity. In many cases, people feel comfortable when helping others by sharing their knowledge; Because they consider this a useful and more effective activity, because strong personal relationships and mutual respect can motivate individuals to fully exchange knowledge with their likes. It was emphasized that reciprocity with trust enhances the exchange of knowledge, since mutual trust is an important factor in developing positive relationships between people, which in turn encourages the process of knowledge exchange (Alstyne, 2005). Also influencing is the desire to participate, and means a positive attitude to other members of The group is ready to respond to their colleagues, where individuals want to provide access to their personal knowledge, but given that their focus is on the group's interest, they expect others to behave similarly and focus on the group's interest as well, and the natural case of this is not to take the initiative easily to participate effectively in their knowledge, if they are not sure whether others are willing to contribute to the interest of the group through sharing and gathering knowledge, therefore knowledge cannot be shared easily, knowledge is not a commodity that can be freely transferred, it is related to the subject of knowledge as well and this is another factor that affects the sharing process, It is the subject on which knowledge is exchanged. People are keen to let others know what they know because they themselves consider it valuable and that their individual knowledge is appreciated by others, and thus in order to learn something from another person there is a need to share knowledge (Wang \& Noe, 2010), and (Brachdia and Falcon, 2014) Indicated to the factors affecting the knowledge sharing process, as I divided them into two parts. The first: factors that positively affect the process of sharing knowledge, and lies in the role of higher departments in activating the process of sharing knowledge, and the role of incentives in improving experiences and exchanging them with other institutions. And exchange experiences of value-added activities for the institution. The second: The factors that negatively affect the process of sharing knowledge. They lie in: complexity, centralization, and the lack of facilities granted by organizations.

\section{Organizational Performance}

Performance is an important subject that has received ample attention in management studies in general; This is due to the importance of the topic at the individual and organizational level and the overlapping of influences that affect performance and its diversity (Shrouf et al, 2020; Jad alRab, 2010) indicated that access to the distinguished job performance of employees is mortgaged and simultaneous with the availability of an acceptable level of services and work and from material and moral justice. Organizational performance occupies a high position in any institution, as the final extract of the outcome of activities in it, at the individual and institution level. Because the institution is more stable and longer lasting when the performance of employees is distinctive, therefore the administration and its leadership pay attention to the level of performance, so the interest in workers is high by the administration. The performance within organizations is not only a reflection of the motivations and capabilities of subordinates, but is also a reflection of the motivations and capabilities of chiefs and leaders as well (Sharif, 2004; Zaid et al, 2015) have defined organizational performance as "the primary driver of enterprise activity, whose aim of its work is to renew." And innovation, just as organizational performance leads to innovation and helps to renew, march, and move forward. Organizational performance represents the institution's ability to define and implement the goals it seeks. "(Garge \& Rastogi, 2006) defined organizational performance as: All of 
INTERNATIONAL JOURNAL OF ACADEMIC RESEARCH IN BUSINESS AND SOCIAL SCIENCES Vol. 10, No. 9, 2020, E-ISSN: 2222-6990 @ 2020 HRMARS

them are in the organization in order to perform the tasks and roles assigned to them, which is reflected in the success or failure of the organization. "Arabiyat (2012) defined it as "the work that subordinates do, which contributes to achieving goals through his understanding of his role and mastery of his work, and following the instructions that it is reached by management, his behavior with colleagues, superiors, and his professional development".

Performance is related to the goals of the organization that you wish to achieve, and performance in all its meanings is related to many concepts related to success and failure, both of which are subject to measurement and evaluation, and the process of measurement and evaluation is based on specific elements according to the vision of the organization and its size, and is based on the strategy and goals that are concerned with the destinations that the service and product will be directed to the organizational structure focuses on the level, efficiency and extent of its ability to serve the processes that produce goods and services, and performance is considered the measure that can be used in a way that serves both strategy and goals, and management is represented in the way it is used to determine trends, and how to make the correction. Organizational effectiveness is the institution's ability to achieve its goals related to the degree of acceptance of its services and its response to developments, and organizational efficiency is evidence of the institution's ability to manage and make good use of the resources available to it, whether human resources, money, equipment, or information to achieve them. And strategic success i.e. the institution's ability to survive, adapt, and grow, in light of the goals it seeks to achieve by achieving a balance between the requirements for survival in the near and long term (Al-Shumaili, 2017).

The performance of the organizational system is a complex set of criteria for performing mutual relationships: effectiveness, efficiency, quality, productivity, innovation and benevolence (Rolstadas, 1998). Organizational performance must be measured at multiple levels: the organizational level, the level of the main process, and the level of the business unit that requires complementary dimensions. Performance measures in the proposed study model include creativity, efficiency, and effectiveness, to be measured at both the organizational level and the level of the business unit.

Efficiency: Competency plays a large role in supporting public and private organizations. Therefore efficiency is the extent to which a resource is used for its intended purpose. Arguably, the process is useful when you use time or energy well (O'Donnell \& Duffy, 2002). Efficiency is the issue of the input and transformation process, and is defined as a ratio of the resources expected to be consumed to the resource actually consumed (Rolstadas, 1998). Efficiency is inherent in any activity, but it is difficult to measure (O'Donnell and Duffy, 2002), necessitating the use of sensory perception measures.

Usually, the organization's ability and efficiency are a result of experience, which represents the accumulation of education experiences and the increase in actual efficiency achieved over time. The experience is built and developed until the organization reaches a good level of efficiency in carrying out the required activities at an appropriate cost so that the process of converting this experience into a real capacity on the ground begins, and after that the efficiency of the organization becomes a competitive ability with effectiveness when the customers prepare the efficiency as an additional value and benefit for them, and when this efficiency plays an effective role, the organization is distinguished from its competitors (Thompson and Strickland, 2006). 
INTERNATIONAL JOURNAL OF ACADEMIC RESEARCH IN BUSINESS AND SOCIAL SCIENCES Vol. 10, No. 9, 2020, E-ISSN: 2222-6990 @ 2020 HRMARS

Creativity: Evolution and progress in our world today depend on creativity. If organizations today do not achieve creativity in new products or services, they will never be competitive. Creativity has been defined as the ability to link ideas in a unique and unfamiliar way (Daft, 2007).

In order for the organization to be creative, it must have a set of incentives for its individuals and workers; To be creative, they are summarized as follows:

A- Human factors: People are the basis for creativity in organizations. Therefore they should be motivated by training and development; Because the educated organization that seeks to train and develop in its employees continuously will lead to that their knowledge is always renewed as training programs gain workers the new skill, and for development it will expand the horizon and awareness of the levels of managers. As for worker safety, giving employees safety will make them not afraid of mistakes, so that they will be pioneers in the processes of change and support new ideas. As for the commitment of the creators, the creators are the ones who benefit from their unique and unfamiliar ideas that can be embodied in the products or services. Therefore, the care and support of the creators will encourage and support them to be more creative.

B- Structure factors: The organizational structure is considered as an organizational map indicating the lines of authority and the functional locations therein, and the structure affects organizational creativity through: the organic structure, the availability of resources, and the availability of communications.

Creative performance is measured externally with products or achievements that can be evaluated or widely observed (Amabile et al, 1996). There are basic factors: organizational climate, leadership style, organizational culture, resources and skills, and the structure and systems of organizations that affect organizational creativity (Andriopoulos, 2001) as well as Innovation in an organization usually refers to the innovative performance of the organization as a whole in a specific time period, usually a year and usually in relation to its production of goods and services (Christensen, 2006). In order to survive and successfully compete, the organization needs a business-friendly innovation strategy, organizational structure, and senior management style, Middle Management Practices and Effective Methods of Innovation Management to Achieve Innovative Success and Competitive Excellence (Khandwalla \& Mehta, 2004).

Effectiveness: means effectiveness (achieving the goals), and means making sure that the use of available resources has led to achieving the desired goals (Al-Ghalibi and Idris, 2007). Effectiveness reflects the completion of work and access to the best possible decisions, and there are indicators of effectiveness, which are:. Output indicators, process indicators, and structural indicators (Al-Taher, 2012). (Al-Ghalibi \& Idris, 2007) believes that measuring the organizational effectiveness lies in two principles: external and internal, as the organizational effectiveness of the internal environment is evaluated on the basis of the degree of the organization achieving the goals related to the volume of sales, market share, and profits, while the effectiveness of the organization for the external environment is measured on the basis of its competitive strength Which depends on the degree of acceptance of its products or services, the degree of its assimilation of technological development and creativity, its sensitivity to economic fluctuations, and its ability to react to it. The efficiency and effectiveness of the organization is greatly dependent on the level of cooperation that prevails among 
INTERNATIONAL JOURNAL OF ACADEMIC RESEARCH IN BUSINESS AND SOCIAL SCIENCES Vol. 10, No. 9, 2020, E-ISSN: 2222-6990 @ 2020 HRMARS

its members, as this cooperation facilitates the organizational process, and keeps the organization away from sophistication (Al-Saadi, 2011).

\section{Hypothesis Development}

The success of any organization is tied to how efficient and effective the organization is; Because the distinguished performance of the individuals working in the organization necessarily means a distinct performance of the institution, given the complexity of the nature of the human element, and because of its great reflection on the results that were reached as a result of distinguishing the human element from other elements of production, as an important resource to be invested in, and this is because of its capabilities in Achieving a competitive advantage that is not often imitated based on the skills, experience and knowledge that it possesses, which technology and machinery are unable to achieve, regardless of the degree of its development if it is isolated from it (Saqr, 2005). All these data made the institution pay much attention to the human element, by following up its performance and evaluating it. To know the strengths and weaknesses in carrying out the work directed to each individual in the organization, by relying on a set of criteria through which this performance is measured and evaluated, the performance of human resources expresses the degree of achieving the tasks that constitute the individual's job and completing it, and it reflects how the individual achieves the job requirements or Satisfy it, and the performance of the individual relates to the various activities and tasks that make up his work (Saqr, 2005). Organizational performance reflects the practical level achieved by the individual when performing the activities required by his job, and performance is considered to be the degree to which the worker attains the goals of the business unit and the goals of the institution, as a result of his behavior and the use of his skills, abilities, and knowledge and there are many important elements that collectively, they are known as the performance of organizations, and without them it is not possible to talk about an effective performance of these resources, due to their importance in determining the level of human resource performance in institutions, and related to knowledge of work requirements (job), quality of work, amount of work, perseverance and reliability (Al-Anazi, 2004)

(Ismail, 2009) indicated that knowledge sharing is related to the behavior of individuals, it must be studied by the performance of human resources, and the outputs of knowledge sharing, which the individual working in the institution contributes to achieve as a result of developing his knowledge, capabilities and development, which is represented in new knowledge and innovations. That contribute to raise organizational performance. Benefits come from knowledge sharing, usually at an individual and organizational level. On an individual level, knowledge management provides opportunities for workers; to enhance their skills through teamwork and knowledge sharing, which allows improving their performance, while knowledge management at the organizational level has two important benefits: improving organizational performance and achieving innovations, as well as the ability to make better decisions, improve operations, integrate data and broad cooperation. (Jones, 2011) also pointed out that there are many concepts that support the relationship between knowledge sharing and performance and believes that knowledge sharing contributes to improving the level of performance since the knowledge that is shared between individuals does not only benefit the institution but also increases the competencies of individuals participating in the process of knowledge sharing through Developing their knowledge, abilities and skills in working independently. 
INTERNATIONAL JOURNAL OF ACADEMIC RESEARCH IN BUSINESS AND SOCIAL SCIENCES Vol. 10, No. 9, 2020, E-ISSN: 2222-6990 @ 2020 HRMARS

The researchers focused on examining the relationship between knowledge management and organizational performance in various business sectors, and it is worth noting that most of these studies were conducted in environments other than the Arab environment. Darroch, (2005), in her study of the nature of the relationship between knowledge management and performance, concluded that the role of knowledge management provides evidence that organizations that tend to increase and develop innovation are more willing to possess advanced knowledge management in their behavioral and applied aspect. The results have provided support for the point of view that: Organizations that possess capabilities in knowledge management are better able to use their available resources effectively, which leads to innovation and better performance, and indicated that the response to knowledge has an impact on financial performance. The Mohamed \& Chen study also indicated that knowledge and its use And sharing it plays a big role in developing the wealth of organizational knowledge, and that the increase and intensification of these two activities increases the space of organizational knowledge that requires a large capacity to spread knowledge, and that the ability to spread knowledge enables the organization to respond more to changes in customer needs, which facilitates and stimulates the acquisition and use of knowledge Implicit in the new implication, which is reflected in knowledge management as an initiative added to the strategic plan of the organization that is intended to lead the improvement of organizational performance Based on the foregoing, the researcher assumes

$\mathrm{H}_{0}$ There is statistically significant effect of knowledge sharing tools on enhancing organizational performance in its dimensions (efficiency, creativity, effectiveness).

The following sub-hypotheses are branched from this hypothesis:

$\mathrm{H}_{01}$ There is statistically significant effect of knowledge sharing tools on enhancing efficiency.

$\mathrm{H}_{02}$ There is statistically significant effect of knowledge sharing tools in promoting creativity.

$\mathrm{H}_{03}$ There is statistically significant effect of knowledge-sharing tools on enhancing efficacy.

\section{Study Methodology}

The researcher adopted the questionnaire to obtain the primary data of the study, as he designed and developed its implications based on what was mentioned by theoretical literature and previous studies related to the subject of the study. The questionnaire consisted of three sections: The first section dealt with the demographic variables of the study sample, and the second section dealt with the dimensions of knowledge sharing, as it was divided into four dimensions: after training, after best practices, after an organizational culture, and after knowledge bases. The third section dealt with organizational performance: efficiency, after effectiveness, and after creativity. The researcher relied on the Likert pentaton scale, where he gave each of the paragraphs mentioned in the questionnaire five degrees of approval (1-5), respectively, where number (5) strongly agreed, number (4) agreed, number (3) agreed to a medium degree, number (2) does not agree, and number (1) is strongly disagree. As for the limits adopted by the researcher in the study to judge the arithmetic mean for the respondents 'answers to the paragraphs related to the study variables, the researcher adopted three levels, namely: (high, medium, Low), and the study population may be among the workers at Jadara University, as the number of employees in it reached (420) employees and employees, as it is a homogeneous society, and the researcher chose a simple random sample from him, consisting of (201) employees and employees by withdrawing them from the study community The researcher distributed (210) questionnaires, and the number of retrieved 
INTERNATIONAL JOURNAL OF ACADEMIC RESEARCH IN BUSINESS AND SOCIAL SCIENCES Vol. 10, No. 9, 2020, E-ISSN: 2222-6990 @ 2020 HRMARS

questionnaires reached (206) ones, and it is valid for statistical analysis (201) questionnaires, based on the table of sample size - Uma Sakran (Sekaran \& Bougi, 2010).

\section{Validity and Reliability}

To verify the validity of the study tool, the questionnaire was presented to a group of (10) arbitrators with specialized and experienced faculty members in the departments of faculties of administration, chosen from several universities; To judge its validity (apparent honesty), with the aim of identifying the availability of the following aspects in the study tool: accuracy of linguistic formulation and clarity in the paragraphs of the questionnaire, the suitability of the paragraphs for the dimension to which they belong, the appropriate extent and comprehensiveness of the questionnaire for all dimensions that measure the variables of the study.

To ensure the consistency of the study tool, the internal consistency was calculated according to the Cronbach alpha equation to measure the consistency of the respondents' answers on all paragraphs of the study tool, and although the rules of measurement in the value to be obtained is considered in terms of application of humanities in general is acceptable (Cronbach Alpha) on it are specific,

The table below shows these factors, and these ratios were considered appropriate for the purposes of the study.

Table (2): Coefficient of internal consistency of Cronbach Alpha

\begin{tabular}{|l|c|c|}
\hline \multicolumn{1}{|c|}{ Domains } & $\begin{array}{c}\text { Internal } \\
\text { consistency }\end{array}$ & $\begin{array}{c}\text { The number of } \\
\text { paragraphs }\end{array}$ \\
\hline Organizational culture & .959 & 6 \\
\hline Training & .766 & 6 \\
\hline Knowledge rules & .884 & 5 \\
\hline Best Practices & .946 & 5 \\
\hline Knowledge Sharing Tools & .870 & 22 \\
\hline Efficiency & .869 & 6 \\
\hline Creativity & .935 & 6 \\
\hline Effectiveness & .829 & 6 \\
\hline Organizational Performance & .930 & 18 \\
\hline
\end{tabular}

Table (2) shows that the values of the stability coefficients (Cronbach Alpha) for the dimensions and fields of study ranged between (766.-995), all of which are high and acceptable values for application purposes.

\section{Description of the Characteristics of the Study Sample}

This part shows the results of the analysis related to the data of the study sample and its distribution according to the demographic and functional variables, which included gender, age, educational qualification, experience, job title, iterations and percentages of the members of the study sample were extracted, and Table (4-1) below shows the distribution of the sample members According to demographic variables. 
INTERNATIONAL JOURNAL OF ACADEMIC RESEARCH IN BUSINESS AND SOCIAL SCIENCES Vol. 10, No. 9, 2020, E-ISSN: 2222-6990 @ 2020 HRMARS

Table (3): Repetitions and percentages according to the study variables

\begin{tabular}{|c|c|c|c|}
\hline & Categories & Repetition & Ratio \\
\hline \multirow{2}{*}{ Sex } & Male & 119 & 59.2 \\
\hline & Female & 82 & 40.8 \\
\hline \multirow{4}{*}{ Age } & Under 25 years old & 5 & 2.5 \\
\hline & From 25 - less than 35 & 127 & 63.2 \\
\hline & -35 less than 45 & 48 & 23.9 \\
\hline & 45 and over & 21 & 10.4 \\
\hline \multirow{2}{*}{ Job title } & Faculty member & 83 & 41.3 \\
\hline & Administrative & 118 & 58.7 \\
\hline \multirow{4}{*}{$\begin{array}{c}\text { Practical } \\
\text { experience }\end{array}$} & Less than 10 years & 35 & 17.4 \\
\hline & From 10 - less than 15 & 95 & 47.3 \\
\hline & From 15 - less than 20 & 43 & 21.4 \\
\hline & 20 years and over & 28 & 13.9 \\
\hline \multirow{5}{*}{$\begin{array}{c}\text { Educational } \\
\text { level }\end{array}$} & Diploma and less & 7 & 3.5 \\
\hline & Bachelor & 52 & 25.9 \\
\hline & M.A. & 97 & 48.3 \\
\hline & Ph.D. & 45 & 22.4 \\
\hline & Total & 201 & 100.0 \\
\hline
\end{tabular}

Table (3) shows the following:

1- The number of males in the sample was (119) with a percentage (59.2\%), while the number of females (82) reached a percentage (40.8\%)

2- The highest percentage of personnel distribution according to the variable of work experience reached $(47.3 \%)$ for the number of years of experience (from 10- less than 15), while the lowest percentage for the number of years of experience (20 years or more) reached by a percentage (13.9\%), and it may return This is due to the interest of the walled university in retaining the highly experienced staff and following the university's polarization policy.

3- The highest percentage of individuals distribution according to the variable of the educational level (48.3\%) for the educational level (masters) and the lowest percentage for the educational level (Diploma and less) reached a percentage (3.5\%), and this may be due to the interest of Jadara University in the research to retain the employees who they hold a university degree (postgraduate) as a minimum for university admission.

4- The highest percentage of individuals distribution according to the age variable (63.2\%) for the age group (from 25 years - less than 35 years) and the lowest percentage for the age variable (less than 25 years) reached a percentage (2.5\%), and this may be due to he target group in most of our society is the youth group more than the other age groups because they are distinguished by vitality and love of work and achieving their goals in the long run.

5- The highest percentage of individuals distribution according to the variable of the job title (58.7\%) of the job title (administrative), while the lowest percentage of the variable (faculty member) reached a percentage $(41.3 \%)$, and this may be due to the interest of Jadara University in the research to attract administrators More than one faculty. 
INTERNATIONAL JOURNAL OF ACADEMIC RESEARCH IN BUSINESS AND SOCIAL SCIENCES Vol. 10, No. 9, 2020, E-ISSN: 2222-6990 @ 2020 HRMARS

\section{Descriptive Statistics}

To answer this question, arithmetic averages and standard deviations were calculated for the estimates of the study sample individuals on the dimensions as a whole and on the paragraphs of each dimension separately, as they were as follows:

Table (4) arithmetic averages and standard deviations for the study variables

\begin{tabular}{|l|c|c|c|}
\hline The dimension & SMA & Standard Deviation & The Level \\
\hline Training & 3.53 & 743. & Mid. \\
\hline Organizational culture & 3.46 & 1.095 & Mid. \\
\hline Knowledge rules & 3.41 & 945. & Mid. \\
\hline Best Practices & 3.36 & 1.154 & Mid. \\
\hline Share Knowledge & $\mathbf{3 . 4 5}$ & $\mathbf{6 1 0}$ & Mid. \\
\hline Effectiveness & 3.78 & .786 & high \\
\hline Creativity & 3.58 & 1.059 & Mid. \\
\hline Efficiency & 3.57 & .870 & Mid. \\
\hline Organizational Performance & $\mathbf{3 . 6 4}$ & .768 & Mid. \\
\hline
\end{tabular}

Table (4) shows that the arithmetic averages ranged between (3.36-3.53), where after training came in the first rank with the highest arithmetic average of (3.53), while it came after best practices in the last rank and with an arithmetic average of (3.36), and the average Arithmetic for knowledge sharing as a whole (3.45). Table (4) also shows that the arithmetic averages ranged between (3.57-3.78), as it came after effectiveness in the first rank with the highest arithmetic average of (3.78), while it came after efficiency in the last rank with an arithmetic average of (3.57), and the average Arithmetic for organizational performance as a whole (3.64).

\section{Study Hypotheses Test}

$\mathrm{H}_{0}$ : The first main hypothesis: There is no statistically significant effect at the level of significance $(0.05 \geq \alpha)$ for knowledge sharing in its dimensions (organizational culture, training, knowledge bases, best practices) in enhancing organizational performance.

Multiple regression analysis of the effect of knowledge sharing in its dimensions (organizational culture, training, knowledge bases, best practices) was used to enhance organizational performance as shown in Table (5). 
INTERNATIONAL JOURNAL OF ACADEMIC RESEARCH IN BUSINESS AND SOCIAL SCIENCES Vol. 10, No. 9, 2020, E-ISSN: 2222-6990 @ 2020 HRMARS

Table No. (5) Analysis of multiple regression of the effect of knowledge sharing in its various dimensions on enhancing organizational performance

\begin{tabular}{|c|c|c|c|c|c|c|c|}
\hline $\begin{array}{l}\text { Independent } \\
\text { variable }\end{array}$ & Beta & $\begin{array}{l}\mathrm{T} \\
\text { Value }\end{array}$ & $\begin{array}{c}\text { Statistical } \\
\text { significance } \\
\mathrm{t}\end{array}$ & $\begin{array}{c}\text { Correlation } \\
\text { coefficient } \\
\text { R }\end{array}$ & $\begin{array}{l}\text { Explanatory } \\
\text { variance R2 }\end{array}$ & $\begin{array}{c}\text { Value } \\
\text { of } \\
f\end{array}$ & $\begin{array}{c}\text { Statistical } \\
\text { significance }\end{array}$ \\
\hline $\begin{array}{c}\text { Organizational } \\
\text { culture }\end{array}$ & .018 & .268 & .789 & \multirow{4}{*}{.802} & \multirow{4}{*}{.636} & \multirow{4}{*}{88.504} & \multirow{4}{*}{.000} \\
\hline Training & $.095-$ & 1.379 & .169 & & & & \\
\hline $\begin{array}{c}\text { Knowledge } \\
\text { rules }\end{array}$ & .237 & 2.787 & .006 & & & & \\
\hline Best Practices & .587 & 6.993 & .000 & & & & \\
\hline
\end{tabular}

Dependent Variable: Organizational Performance

It is clear from the above table that there is a statistically significant effect at the level of significance $(\alpha=0.05)$ of the effect of knowledge sharing of its dimensions (organizational culture, training, knowledge bases, best practices) in enhancing organizational performance, where the correlation coefficient $R(.802)$ has reached Explanatory variance $R^{2}$ amounted to (636), meaning that knowledge sharing in its dimensions (organizational culture, training, knowledge bases, best practices) explained (63.6\%) of the varied accident in enhancing organizational performance at Jadra University, and the value of " $F$ " (88.504) and with a statistical significance (.000), which indicates the rejection of the null hypothesis and the acceptance of the alternative hypothesis which states that: "There is a statistically significant effect at the level of significance $(0.05 \geq \alpha)$ to share knowledge of its dimensions (organizational culture, training, knowledge bases Best practices) in enhancing organizational performance.

\section{The Following sub-hypotheses are Branched from this Hypothesis}

The first sub-hypothesis: There is no statistically significant effect at the significance level $(0.05 \geq \alpha)$ to share knowledge in the level of efficiency enhancement.

To verify the validity of this hypothesis, multiple regression analysis was used for the effect of dimensions of knowledge sharing in the level of efficiency enhancement as shown in the following tables.

Table (6) multiple regression analysis of the effect of dimensions of knowledge sharing in the level of efficiency enhancement

\begin{tabular}{|c|c|c|c|c|c|c|c|}
\hline $\begin{array}{c}\text { Independent } \\
\text { variable }\end{array}$ & Beta & T Value & $\operatorname{sig} t$ & $\mathrm{R}$ & $\mathrm{R} 2$ & $f$ & sig \\
\hline $\begin{array}{c}\text { Organizational } \\
\text { culture }\end{array}$ & .094 & 1.393 & .165 & \multirow{4}{*}{.804} & \multirow{4}{*}{.640} & \multirow{4}{*}{89.826} & \multirow{4}{*}{.000} \\
\hline Training & $.084-$ & 1.229- & .220 & & & & \\
\hline $\begin{array}{c}\text { Knowledge } \\
\text { rules }\end{array}$ & .060 & .713 & .477 & & & & \\
\hline Best Practices & .765 & 9.162 & .000 & & & & \\
\hline
\end{tabular}

Dependent variable: efficiency 
INTERNATIONAL JOURNAL OF ACADEMIC RESEARCH IN BUSINESS AND SOCIAL SCIENCES Vol. 10, No. 9, 2020, E-ISSN: 2222-6990 @ 2020 HRMARS

It is clear from the above table that there is a statistically significant effect at the level of significance ( $\alpha=0.05$ ) of the effect of knowledge sharing in its dimensions (organizational culture, training, knowledge bases, best practices) in enhancing efficiency, where the correlation coefficient $R(.804)$ and the coefficient of determination of variance Interpreter $R^{2}$ amounted to (.640), meaning that knowledge sharing in its dimensions (organizational culture, training, knowledge bases, best practices) explained $64 \%$ of the variance that occurred in enhancing efficiency in Jadara University and the value of "F" (89.826) and statistically significant (.000), which indicates the rejection of the null hypothesis and the acceptance of the alternative hypothesis which states that "there is a statistically significant effect at the significance level $(0.05 \geq \alpha)$ for knowledge sharing of its dimensions (organizational culture, training, knowledge bases, best practices) in enhancing efficiency

The second sub-hypothesis: There is no statistically significant effect at the significance level $(0.05 \geq$ $\alpha)$ to share knowledge in the level of creativity enhancement.

To verify the validity of this hypothesis, multiple regression analysis was used for the effect of dimensions of knowledge sharing in the level of creativity enhancement as shown in the following tables.

Table (7) Analysis of multiple regression of the effect of dimensions of knowledge sharing in the level of enhancing creativity

\begin{tabular}{|c|c|c|c|c|c|c|c|}
\hline $\begin{array}{l}\text { Independent } \\
\text { variable }\end{array}$ & Beta & $\begin{array}{c}\mathrm{T} \\
\text { Value }\end{array}$ & Sig $t$ & $\mathrm{R}$ & $\mathrm{R} 2$ & $f$ & sig \\
\hline $\begin{array}{c}\text { Organizational } \\
\text { culture }\end{array}$ & $.060-$ & $.742-$ & .459 & \multirow{4}{*}{.701} & \multirow{4}{*}{.481} & \multirow{4}{*}{47.316} & \multirow{4}{*}{.000} \\
\hline Training & $.096-$ & 1.167- & .245 & & & & \\
\hline $\begin{array}{c}\text { Knowledge } \\
\text { rules }\end{array}$ & .364 & 3.579 & .000 & & & & \\
\hline Best Practices & .337 & 3.357 & .001 & & & & \\
\hline
\end{tabular}

Dependent variable: creativity

It is clear from the above table that there is a statistically significant effect at the level of significance ( $\alpha=0.05$ ) of the effect of knowledge sharing in its dimensions (organizational culture, training, knowledge bases, best practices) in enhancing creativity, where the correlation coefficient $R(.0101)$ and the coefficient of determination of variance Interpreter $R^{2}$ amounted to (.481), meaning that knowledge sharing in its dimensions (organizational culture, training, knowledge bases, best practices) explained $48.1 \%$ of the variance that occurred in the promotion of creativity at Jadara University, and the value of "F" (47.316) was statistically significant (.000), which indicates the rejection of the null hypothesis and the acceptance of the alternative hypothesis which states that "there is a statistically significant effect at the significance level $(0.05 \geq \alpha)$ for knowledge sharing of its dimensions (organizational culture, training, knowledge bases, best practices) in promoting creativity.

The third sub-hypothesis: There is no statistically significant effect at the significance level $(0.05 \geq \alpha)$ to share knowledge in the level of effectiveness enhancement. 
INTERNATIONAL JOURNAL OF ACADEMIC RESEARCH IN BUSINESS AND SOCIAL SCIENCES Vol. 10, No. 9, 2020, E-ISSN: 2222-6990 @ 2020 HRMARS

To verify the validity of this hypothesis, multiple regression analysis was used to effect the dimensions of knowledge sharing in the level of effectiveness enhancement as shown in the following tables.

Table (8) Analysis of multiple regression of the effect of dimensions of knowledge sharing in the level of enhancing effectiveness

\begin{tabular}{|c|c|c|c|c|c|c|c|}
\hline $\begin{array}{c}\text { Independent } \\
\text { variable }\end{array}$ & Beta & T Value & Sig $t$ & $\mathrm{R}$ & $\mathrm{R} 2$ & $f$ & Sig \\
\hline $\begin{array}{c}\text { Organizational } \\
\text { culture }\end{array}$ & .030 & .318 & .751 & \multirow{4}{*}{.540} & \multirow{4}{*}{.277} & \multirow{4}{*}{20.202} & \multirow{4}{*}{.000} \\
\hline Training & $.056-$ & $.576-$ & .565 & & & & \\
\hline $\begin{array}{c}\text { Knowledge } \\
\text { rules }\end{array}$ & .138 & 1.153 & .250 & & & & \\
\hline Best Practices & .421 & 3.556 & .000 & & & & \\
\hline
\end{tabular}

Dependent variable: efficacy

It is clear from the above table that there is a statistically significant effect at the level of significance ( $\alpha=0.05$ ) of the effect of knowledge sharing in its dimensions (organizational culture, training, knowledge bases, best practices) in enhancing effectiveness, where the correlation coefficient $R(.540)$ and the coefficient of determination of variance Interpreter $\mathrm{R}^{2}$ amounted to (.277), meaning that knowledge sharing in its dimensions (organizational culture, training, knowledge bases, best practices) explained $27.7 \%$ of the variance that occurred in enhancing effectiveness in the Jadara University and the value of "F" (20.202) and with statistical significance (.000), which indicates the rejection of the null hypothesis and the acceptance of the alternative hypothesis which states that "there is a statistically significant effect at the significance level $(0.05 \geq \alpha)$ for knowledge sharing of its dimensions (organizational culture, training, knowledge bases, best practices) in enhancing effectiveness.

\section{Results}

The study showed that the level of knowledge sharing was average, and the reason is that the university administration encourages the exchange of ideas, flexible thinking among them and the employees, and the university administration seeks to achieve its specific goals at the shortest possible time, and this result agreed with the result of the study of Durra \& Others (2018) and the study of Al-Taher \& Mansour (2011), which concluded that the level of knowledge sharing practice was moderate in Jordan Telecom companies and Thafar University in the Sultanate of Oman. The study agreed with a study (Yaghi, 2011) in the academic community, which is the University of Applied Sciences in Jordan, but it differed in the dimensions of knowledge sharing, as it took the factors that support knowledge sharing behaviors at the university that included university culture, administrative structure, students themselves, and information resources. The study also showed that the level of organizational performance was average, due to the fact that the university administration seeks to attract individuals who have creative capabilities to work in the university, and that the university administration possesses the ability to perform its work and implement its activities in the correct and appropriate way. The study agreed with the study (Al-Azmi \& Al-Hajri, 2018) and the study (Richard \& George, 2006) where the level of organizational performance in Kuwait University and in the public sector was average in all its dimensions. This finding differed with 
the result of a study Katous \& Budhwar (2007), which found that the level of practice in organizational performance in Greek companies was low.

The results of the hypothesis test showed that there is a statistically significant effect of knowledge sharing in its dimensions (organizational culture, training, knowledge bases, best practices) in enhancing organizational performance at Jadara University, due to the fact that the university administration encourages the exchange of ideas between employees and their development by dealing with team spirit among them, which contributes to the use of best practices to increase the skills of working individuals. This study was in agreement with the study (Al-Khshali and Al-Hawamdeh, 2019) which found a statistically significant effect of knowledge sharing on the quality of work life in Jordanian food industry companies. It coincided with the study (Al-Khshali, 2009), which found a statistically significant relationship between the components of knowledge management (knowledge acquisition, knowledge dissemination, and response to knowledge) as well as a significant effect of knowledge response on internal performance, as well as compatible with a study (Obeidat \& Otibi, 2015), Which found that there is an important statistical effect of knowledge sharing in organizational learning at three levels in Jordanian commercial banks. Organizational culture - as a means of knowledge sharing - has had the most significant impact on organizational learning.

The results of the sub-hypothesis test showed that there is a statistically significant effect of knowledge sharing in enhancing competence at Jadara University; This is due to the fact that the university administration possesses the ability to perform its work and implement its activities in the correct and appropriate way, and also seeks to achieve its specific goals at the shortest possible time, and there is a statistically significant effect of knowledge sharing in promoting creativity at the Jadara University. "The reason for this that the university administration is keen to provide a creative work environment that contributes to improving the ability to take creative decisions in it. The results also showed a statistically significant effect of knowledge sharing in enhancing effectiveness in the University of Jadra; The reason for this is because the university management has goals it is verifiable and adopts methods and procedures aimed at achieving quality in the services it provides, and the university administration relies on clear and specific performance measures to measure its performance. 
INTERNATIONAL JOURNAL OF ACADEMIC RESEARCH IN BUSINESS AND SOCIAL SCIENCES

Vol. 10, No. 9, 2020, E-ISSN: 2222-6990 @ 2020 HRMARS

\section{References}

Ababneh, R. I., Aladwan, Y. M. (2008). Factors influencing the practice of organizational learning in the municipalities of Jordan, the journal Public Administration, 48(3) 439-455.

Mohsen, A. T. (2002). Performance evaluation: new entrances to a new world, Beirut: Dar Al-Fikr AlArabi and the Arab Renaissance

Abdel-Baqi, S. A. (2003). Organizational behavior: contemporary Organizational Entrance, New University House, Alexandria.

Abdul-Malik, J., \& Zakia, J. (2015). The impact of nnowledge sharing on the efficiency of higher education professors: A field study in the faculty of economic, commercial and management sciences at the university of bordj bou arreridj. Journal of Economic Insights, University of the Martyr Hama, the martyr Hamma Lakhdar, Algeria (8) 1.

Abu Ziyad, Z. (2011). the Impact of applying total quality management concept on organizational performance: an applied study in a sample of palestinian commercial banks. An-Najah University Journal for Research, 25(4) 879-932.

Adams, K. (2005). The Sources of Innovation and Creativity. National Center on Education and the Economy (NJ1).

Al Thani, F. B. H., \& Obeidat, A. M. (2020). The Impact of Strategic Leadership on Crisis Management. International Journal of Asian Social Science, 10(6) 307-326.

Al-Amyan, M. S. (2005). Organizational behavior in business organizations, $3^{\text {rd }}$ floor, Darwel Publishing, Amman.

Al-Anazi, M. (2004). Organizational Change and its relationship with employee performance: a survey study of workers in Riyadh traffic department, master thesis in Administrative Sciences, Naif Arab University for Security Sciences, Riyadh, Saudi Arabia.

Al-Atani, H. A. (2007). Training: its Concept, its effectiveness, building and evaluating training programs, Amman: Al-Shorouk Publishing House.

Al-Azmi, M. A. S. (2018). The reality of applying modern roles for human resources management in kuwait university and its impact on organizational performance, kuwait. Educational Journal, 30(128) 294-317.

Al-Azzawi, S. F. (2009). the culture of business organizations: concepts and foundations and applications, Riyadh: Institute of Public Administration.

Al-Barashdia, K. B., \& Al-Saqri, M. B. (2014). Knowledge sharing between Industrial establishments in the sultanate of oman. Journal of Arts and Social Sciences, Sultan Qaboos University.2(5) 106122.

Al-Ghalbi, T. M., \& Idris, W. M. S. (2009). Strategic management, an integrated systematic Perspective, Amman, Jordan, Wael Publishing and Distribution House.

Alghamdi, Y. S. (2020). The Impact of knowledge sharing on the services provided by of security and safety employees in Saudi telecom company, Arab Journal of Sciences and Research Publishing .6 (1) $17-43$.

Al-Haiti, K. (2003). Human Resources Management: A strategic entrance, Amman: wael Publishing House.

Al-Hawajrah, K. (2010). the Concept of an educated organization in Jordanian universities from the viewpoint of faculty members. The Jordanian Journal of Business Administration, 6 (1) 225-245. 
INTERNATIONAL JOURNAL OF ACADEMIC RESEARCH IN BUSINESS AND SOCIAL SCIENCES Vol. 10, No. 9, 2020, E-ISSN: 2222-6990 @ 2020 HRMARS

Alizadeh, A., \& Tavangarzadeh, S. (2020). The Influence of organizational citizenship behavior In improving the organizational performances, International Journal of Human Capital in Urban Management (JHCUM) Homepage: http://www.ijhcum.net/Alsakarneh,

Al-Jadaya, M. N. (2008). The level of use of information and communication technology tools and its effect on organizational performance in jordanian industrial companies,. Jordanian Journal of Business Administration, 4 (2) 68-74.

Aljawarneh, N. M., Sokiyna, M., Obeidat, A. M., Alomari, K. A. K., Alradaideh, A. T., \& Alomari, Z. S. (2020). The Role of CRM fog computing on innovation and customer service quality: An empirical study. Marketing and Management of Innovations, (2), 287.

Al-Khshali, S., \& Al-Hawamdeh, M. (2019). Knowledge sharing and its impact on the quality of work life. A field study in Jordanian food industries companies. Journal of the Islamic University for Economic and Administrative Studies, 27 (3)119-148.

Al-Khshali, S. J. (2009). Knowledge management and its impact on organizational performance: A field study in jordanian industrial companies.. Arab Journal of Management, 29(1) 97-121.

Al-Othman, M. (2003). Delegation of authority and impact on efficiency, Unpublished Message, Naif University for Security Sciences, Riyadh, Saudi Arabia.

Al-Qarala, E. (2008). The effect of the characteristics of governance on job performance from the viewpoint of workers in the jordanian ministry of interior, Unpublished Master's Thesis, Mu'tah University, Jordan.

Al-Qudah, S., Obeidat, A. M., \& Shrouf, H. (2020). The impact of strategic human resources planning on the organizational performance of public shareholding companies in Jordan. Problems and Perspectives in Management, 18(1), 219.

Al-Saadi, M. (2011). Contemporary intellectual developments in organizational behavior and human resource management, Al-Warraq for publication and distribution: amman

Al-Saeed, I. (2012), developing the institutional performance of the college of education at taif university in light of quality assurance and accreditation standards. Journal of Reading and Knowledge, Egypt.

Al-Sharida, S. (2008), Job Satisfaction: theoretical frameworks and practical applications, Amman : AlSafa House for Publishing and Distribution.

Al-Shimi, A. (2009). Knowledge management: alternative head of literature, Cairo : Dar Al Fajr for Publishing and Distribution.

Al-Shumaili, A. (2017). Modern strategic management: strategic planning - organizational building creative leadership - control and governance, Cairo: Al-Fajr House for Publishing and Distribution.

Alstyne, M. (2005). Create colleagues, not competitors. Harvard Business Review, 83(9), 24-25.

Al-Taher, A., \& Mansour, I. (2011). Requirements for knowledge sharing and obstacles facing its application in Jordanian telecommunications companies. Available at www.jps-dir.com:

Al-Taher, A. (2011). Knowledge management, Amman : Wael Publishing House.

Alyan, M. (2010). Knowledge management, Amman: Safaa House for Publishing and Distribution.

Amabile, T. M. (1983). the social psychology of creativity: a componential conceptualization. Journal of Personality and Social Psychology, 45 (2) 357-77.

Andriopoulos, C. (2001). Determinants of Organizational Creativity: A Literature Review. Management Decision, 39 (10) 834-40. 
INTERNATIONAL JOURNAL OF ACADEMIC RESEARCH IN BUSINESS AND SOCIAL SCIENCES Vol. 10, No. 9, 2020, E-ISSN: 2222-6990 @ 2020 HRMARS

Antony, J. P., \& Sanghamitra, B. (2010). Measuring organizational performance and organizational excellence of SMEs - Part 1: a conceptual framework, 14 (2) 3-11, Q Emerald Group Publishing Limited.

Arabiyat, B. (2012). The prevailing patterns of educational leadership among the heads of academic departments at Al-Balqa applied university and its impact on the job performance of faculty members (College of Technology Engineering (Case Study). Journal of the Islamic University for Educational and Psychological Studies, 20(2) 705-739.

Awad, E. M., \& Ghaziri, M. H. (2004). Knowledge management, New Jersey: Pearson education International -Prentice Hall.

Baghdadi, A. H., \& Al-Abadi, F. H. D. (2010). Organizational learning and learning organization and its relationship to contemporary administrative concepts, Oman: Warraq Foundation for publication and distribution.

Balawi, M. (2008). Administrative empowerment and its relationship to job Performance among public school teachers in Al-wajh governorate, Saudi Arabia from their point of view, unpublished Master Thesis, Mu'tah University, Jordan. 4(1) 85-99.

Bataineh, M. T., \& Almshakbh, Z. M. (2010). Knowledge management theory and practice, Oman: House sitter time for publication and distribution.

Bhirud, S., Rodrigues, L., \& Desai, P. (2005). Knowledge sharing practices in KM: a case study in Indian software subsidiary. Journal of Knowledge Management Practice, 6(2), 83-90.

Bilal, K. (2010). Administrative contemporary studies, $2^{\text {nd }}$ ed Amman: Dar march for publication and distribution.

Bukhamkham, A., \& Harum, E. (2010). Managing the Job Performance of Human Resources in the Economic Establishment: A Field Study of Composite Shovels and Cranes. the Journal of Economy and Society, 6 p. 57.

Burgda, H., \& Drees, N. (2015). The impact of knowledge sharing on the performance of human resources: A study of the TV production and digital future unit of the condor electronics corporation in Algeria. Jordanian Journal of Business Administration, 4 (11).

Burke, M. A. (2011). Global perspectives on knowledge sharing: investigating malaysian online community behavior, culture and change in organizations, Universidad San Pablo.

Cabrera A,C C.(2002). Knowledge- Sharing. Dilemmas Organization Studies, 23(5); 687-710

Calantone, R. J., Cavusgil, S. T., \& Zhao, Y. (2002). Learning orientation: firm innovation capability and firm performance. Industrial Marketing Management, 31(6) 15-24.

Charlotte, F. (2009). L'entreprise apprenante: knowledge management an question, Paris: I'Harmattan.

Christensen, K. S. (2006). Losing innovativeness: the Challenge of Being Acquired. Management Decision, 44 (9) 1161-82.

Civi, E. (2000). Knowledge management as a competitive asset: a review. Marketing Intelligence \& Planning, 18: 166-76

Daft, M. (2007). Management the new work place Canad: Thomson,south-western .

Davis, D., \& Daley, B. (2008). The learning organization and its dimensions as key factors in firm" performance. Human resource development international, 11(1) 51-66.

Denning, S. (2006). The steps to get more business value from knowledge management, Strategy \& Leadership, 34: 11-16. 
INTERNATIONAL JOURNAL OF ACADEMIC RESEARCH IN BUSINESS AND SOCIAL SCIENCES

Vol. 10, No. 9, 2020, E-ISSN: 2222-6990 @ 2020 HRMARS

Dora, I. A., \& Sabagh, Z.N. (2010). Human resource management in the atheist and the twentieth century: the regulatory curve, Amman: Dar Wael for publication and distribution.

Durrah, O., Gharib, M., \& Baamar, A. (2018). The role of organizational culture in improving the process of knowledge sharing between faculty members at Dhofar University, Administrative Journal, fortieth year, number, 152.

El Bataina, M., \& El Mashaghiba, Z. (2010).Knowledge management between theory and application, Amman: Dar Djalees El Zamman for Publishing and Distribution.

Fernandez, I., Gonzalea, A., \& Sabherwal, R. (2004). Knowledge management: challenges, solutions, technologies, New Jersey, Pearson education.

Garge,p, \& Rastogi, R. (2006). New model of job design: motivating employees performance. Journal of Management Studies,6(1) 36-52.

Hamshiri, O. A. (2013). Knowledge management, the Path to Excellence and Entrepreneurship, Amman : Dar Safaa for printing, publishing and distribution.

Harem, H. (2004). Organizational behavior: The behavior of individuals and groups in business organizations. Amman: Dar Al-Hamid for Publishing and Distribution.

Harem, H. (2010), Organizations Management - A Holistic Perspective, $2^{\text {nd }}$ Ed, Amman: Dar Al-Hamid for Publishing and Distribution.

Hasaballah, A. H., Ali, I., \& Abdullah, M. (2012). The impact of the internal environment of the organization on the knowledge participation of workers (A Study in the Public Services Sector). Journal of Humanities and Economic Sciences, (1) 1-11.

Hassan, R. (2001). Human resources management - A future vision, Alexandria: University Printing and Publishing House.

Hijazi, H. A. I. (2005). Measuring the impact of knowledge management in employing the jordanian organizations: a comparative analysis between the public and private sectors towards building a model for the employment of knowledge management, doctoral thesis unpublished, College of Business Administration, Finance and Graduate Studies, Amman Arab University for Graduate Studie

Holste, J., and Fields, D. (2010). Trust and tacit knowledge sharing and use. Journal of Knowledge Management, 14(1):128-140

Ikhsan, S. (2004). Knowledge management in a public organization: A study on the relationship between organizational elements and the performance of knowledge transfer. Journal of Knowledge Management, 8(2) 95-111

Irtaimeh, H. J., Obeidat, A. M., Abualloush, S. H., \& Khaddam, A. A. (2016). Impact of Business Intelligence on Technical Creativity: A Case Study on Al Hekma Pharmaceutical Company. European Scientific Journal, 12(28), 502-519.

Ismail, M. B. (2009), The relationship between knowledge sharing employee performance and service delivery in Public sector originations: The theoretical framework. public sector ICT management review, 3(1): 38.

Jad Al-Rab, S. M. (2010). Modern trends in business administration, Cairo: Shatat Publishing and Distribution House.

Jawharah, A. (2014). The impact of strategic leadership on knowledge sharing: A case study of an algerian hotel group, PhD thesis, University of Biskra.

Jones, M. E. (2011). Knowledge management: concepts, methodologies, tools and applications, Heshey, USA. 
INTERNATIONAL JOURNAL OF ACADEMIC RESEARCH IN BUSINESS AND SOCIAL SCIENCES

Vol. 10, No. 9, 2020, E-ISSN: 2222-6990 @ 2020 HRMARS

Katou \& Budhwar. (2007). The impact of human resource management policies on Organizational Performance In Greek, Manufacturing Firms Thunderbird. International Business Review, 49 (1) 98-138

Khandwalla, P. N., Mehta, K. (2004). Design of corporate creativity. Vikalpa, 29 (1), 13-28.

Mahamid, A. (2011). The relationship between knowledge sharing and the individual's ability to adapt - a field study in the industrial companies listed on the amman financial market. Jordanian Journal of Business Administration, 7 (2) 246-267.

Muhammad, D. (2019). The reality and trends of knowledge sharing among turkish mardin university students. Arab Journal of Science and Research Publishing, (3) 3.

O’Donnell, F. J., \& Duffy, A. H. B. (2002). Modeling design development performance, International Journal of Operations and Production Management, 22 (11) 1198-221.

Obeidat, A. M., Otibi, G. A. (2015). The Impact of Knowledge Sharing Tools on Levels of Organizational Learning : Field Study on Jordanian Commercial Banks. Australian Journal of Basic and Applied Sciences, 9(5) 253-267.

Obeidat, A. (2019). IT Adaption with Knowledge Conversion Process (SECI). Management Science Letters, 9(13), 2241-2252

Obeidat, A. M., \& Otibi, G. A. (2015). The impact of knowledge sharing tools on levels of organizational learning (Field Study on Jordanian Commercial Banks). Australian Journal of Basic and Applied Sciences, 9(5), 253-267.

Obeidat, A. M., Abualoush, S. H., Irtaimeh, H. J., Khaddam, A. A., \& Bataineh, K. A. (2018). The role of organisational culture in enhancing the human capital applied study on the social security corporation. International Journal of Learning and Intellectual Capital, 15(3), 258-276.

Rebentisch, P. R. (2013). Into the Black Box: The Knowledge Transformation Cycle. Management Science, 49( 9) 1180-1195.

Refaiy, M., \& Labib, A. (2009). The effect of applying tacit knowledge maintenance performance: An empirical study of the energy sector in the UK and Arab Countries. Knowledge Management Research \& Practice, 77: 277-28

Richard, M., \& George, A. (2006).Strategy content and organizational performance : an empirical analysis, ISI Journal, 79 (2) 163-194

Rolstadas, A. (1998). Enterprise performance measurement. International Journal of Operations and Production Management, 18 (10) 989-99

Saffar, N., \& Obeidat, A. (2020). The effect of total quality management practices on employee performance: The moderating role of knowledge sharing. Management Science Letters, 10(1) 77-90.

Salman, Q. (2018). The impact of knowledge sharing on organizational creativity: A test study in the arab company for detergents and chemicals. Tikrit University Journal of Administrative and Economic Sciences, (19) 72.

Saqr, A. (2005). Human behavior in organizations, Egypt: University Knowledge House,.

Sekaran, U. (2011). Research methods for business: a skill-building approach, 5ed, New York: john Wiley and sons inc.

Sharif, T. (2004), leadership styles and their relationship to job performance from the perspective of workers in the Emirate of Makkah Al-Mukarramah, unpublished Master Thesis, Naif Arab University for Security Sciences, Riyadh. 
INTERNATIONAL JOURNAL OF ACADEMIC RESEARCH IN BUSINESS AND SOCIAL SCIENCES

Vol. 10, No. 9, 2020, E-ISSN: 2222-6990 @ 2020 HRMARS

Shrouf, H., Al-Qudah, S., Khawaldeh, K., Obeidat, A., \& Rawashdeh, A. (2020). A study on relationship between human resources and strategic performance: The mediating role of productivity. Management Science Letters, 10(13), 3189-3196.

Swift, P., and Hwang, A. (2013). The impact of affective and cognitive trust on knowledge sharing and organizational learning, The Learning Organization, 20(1): 20-37.

Tawfiq, A. R. (2007). The training has its origins and principles, Encyclopedia of Training and Human Development, Center for Professional Good Work, Cairo.

Thompson, A. A. (2003). Strategic management concepts and cases/por Arthur A. Thompson Jr., AJ Strickland 111 (No. 658.4 T4.).

Titi, I. (2010), Knowledge management: challenges, techniques and solutions, Amman: Dar Al-Hamid for Publishing and Distribution.

Wang, S., \& Noe, R. A. (2010). Knowledge sharing: A review and directions for future research. Human resource management review, 20(2), 115-131.

Yaghi, K. B. (2011). Knowledge sharing degree among the undergraduate students: a case study at applied science private university. International Journal of Academic Research, 3 ( 1) 4-20.

Zaied, R. (2015). The Relationship Between Organizational Innovations, Internal Sources of knowledge and organizational Performance. The journal of Managing Value and Supply chains ljmvsc, 6(1)143-149. 